\section{Suppression of Phytophthora Root Rot in Red Raspberries with Cultural Practices and Soil Amendments}

\author{
Kevin Maloney and Marvin Pritts \\ Department of Horticulture, Cornell University, Ithaca, NY 14886
}

Wayne Wilcox

Department of Plant Pathology, New York State Agricultural Experiment Station, Geneva, NY 14456

Mary Jo Kelly

Department of Horticulture, Cornell University, Ithaca, NY 14886

Additional index words. compost, gypsum, lime, metalaxyl, phosphorous acid, raised beds

\begin{abstract}
Various soil amendments and cultural practices were examined in both a phytophthora-infested (Phytophthora fragariae var. rubi) (+PFR) and uninfested field (-PFR) planted to 'Heritage' red raspberries. Although plants in the +PFR field did not exhibit typical disease symptoms due to unseasonably dry weather, their growth was less than those in the -PFR field. After 2 years, plants in the +PFR site had the highest yields in plots treated with phosphorous acid or amended with gypsum, whereas compost-amended plots had the lowest yields in both +PFR and -PFR sites. A second field study confirmed the positive effect of gypsum on growth and yield of raspberries in an infested site. In a third study, 'Titan' raspberries grown under greenhouse conditions in pots containing unamended soil from the infested site, then flooded, exhibited severe disease symptoms; however, pasteurization of the soil, treatment with phosphorous acid and metalaxyl fungicide, or gypsum amendment mostly prevented symptoms from developing. These three studies suggest that a preplant soil amendment containing certain readily available forms of calcium, such as found in gypsum, can help suppress phytophthora root rot and increase survival, growth and yield of raspberries in sites where the pathogen is present.
\end{abstract}

Phytophthora root rot (PRR) is a severe disease in all major raspberry-producing regions of the world, including North America (Converse and Schwartze, 1968; Wilcox, 1989), South America (Latorre and Munoz, 1993; Wilcox and Latorre, 2002), Europe (Duncan et al., 1987; Graberg, 1994; Heiberg, 1995; Ilieva et al., 1995; Kennedy and Duncan, 1995), and Australia (Washington, 1988). Phytophthora fragariae var. rubi is one of ten Phytophthora species pathogenic on raspberry and is now recognized as the causal organism most commonly associated with severe root rot and decline, particularly in the cooler growing regions of the Americas and northern Europe (Duncan et al., 1997; Wilcox et al., 1993; Wilcox and Latorre, 2002)

Cultural techniques to suppress subterranean phytophthora diseases vary by cropping system. Apple trees grown in either a grass sod or crown vetch ground cover vegetation management system remained free from phytophthora root and crown rot symptoms (Merwin et al., 1992), while adjacent trees grown in other systems, particularly straw mulch, became diseased. Heiberg (1995) and Wilcox et al. (1999b) also found that mulches enhanced PRR development in raspberry plantings. Control of PRR in cranberry (Vaccinium macrocarpon Ait.) is aided by improving surface drainage and adding large volumes of sand to reduce the

Received for publication 17 Jan. 2005. Accepted for publication 8 Apr. 2005. incidence and duration of saturated conditions where water surrounds runners and roots in the soil (Caruso and Wilcox, 1990). Selection and modification of planting sites to provide rapid drainage of water away from the base of peach trees assisted in phytophthora disease control (Wilcox and Ellis, 1989). Similarly, the use of raised beds in raspberry production has reduced PRR development in several field trials (Heiberg, 1995; Maloney et al., 1993; Wilcox et al., 1999b).

Mefenoxam (Ridomil Gold, Syngenta Crop Protection, Inc., Greensboro, N.C.), is registered for control of PRR on in raspberries in the United States. It is the active enantiomer of the formerly-registered metalaxyl, (Ridomil, Ciba-Geigy Corp., Greensboro, N.C.). These fungicides are applied to the soil as a drench and are absorbed rapidly by plant roots and translocated throughout the plant (Carris and Bristow, 1987). Fruityield of untreated raspberry plants was $28 \%$ of that in the metalaxyl-treated plants in a Washington site naturally infested with P. fragariae var. rubi (Bristow and Windom, 1992). Metalaxyl has been beneficial when used as a component of an integrated management system including raised beds and/or genetic host resistance (Maloney et al., 1993; Wilcox et al., 1999b). Various forms of phosphorous acid also have been used in the management of different phytophthora diseases (Bristow and Windom, 1992; Lim et al., 1990; Pegg et al., 1990; Wicks and Hall, 1990).

Little is known about how soil amendments, such as compost, fertilizer, and limestone, influence Phytophthora in raspberry plantings. In Queensland, Australia, an avocado (Persea americana Mill.) grove remained free of disease symptoms in the presence of $P$. cinnamomi inoculum, a phenomenon attributed to suppressive soils. The suppressive soil had higher levels of organic matter, exchangeable $\mathrm{Ca}, \mathrm{Mg}$, and $\mathrm{N}$, and biological activity than did conducive soils (Broadbent and Baker, 1974). Conversely, composted hardwood bark was unsatisfactory for control of apple collar rot caused by P. cactorum (Ellis et al., 1986). An investigation of orchard management practices and their effects on phytophthora root and crown rot of apple indicated that high soil $\mathrm{K}$ and high soil matric water potential were strong predictor variables for disease incidence (Merwin et al., 1992). However, a review of the role of essential nutrients and their influence on phytophthora diseases showed no consistent effects of individual chemicals (Schmitthenner and Cannaday, 1983).

Soil applications of gypsum $\left(\mathrm{CaSO}_{4}\right)$ significantly increased plant growth, fruit yield, and root growth, and reduced populations of P. citricola in an avocado planting (Menge et al., 1994). In a replicated greenhouse study, avocado plants grown in gypsum-amended soil infested with $P$. cinnamomi had a significantly lower percentage of diseased roots than those grown in nonamended infested soil (Messenger-Routh et al., 1996). Gypsum-amended field soil significantly reduced root rot caused by $P$. parasitica in citrus trees (Nemec and Lee, 1995). Ginseng (Panax quinquefolium L.) grown in the absence of calcium showed a net loss of plant fresh weight and rotting of the root system, but rotting was not observed when other elements were withheld (Stolz, 1982).

The objective of this study was to examine the ability of selected cultural practices and soil amendments to suppress Phytophthora fragariae var. rubi in raspberries.

\section{Materials and Methods}

Field experiment 1. Two sites at Cornell Orchards in Ithaca, N.Y., were selected, one of which had been in continuous raspberry production for the previous 10 years and was infested with $P$. fragariae var. rubi (+PFR). A second site directly adjacent to it was selected as a pathogen-free site (-PFR). The -PFR site had been an apple orchard for 50 years before being fallow for 10 years. To the best of our knowledge, $P$. fragariae var. rubi was not introduced to this site before our experiment; furthermore, this organism is essentially hostspecific, and raspberries had never been grown there. The soil at both sites is a Hudson silty clay loam (Typic Hapludalf). However, since their cropping and soil management histories were different, soil bulk density and moisture holding capacity were determined from 7.6 $\times 8.0$-cm cylindrical cores sampled in Nov . 1995 , at a profile depth of 10 to $18 \mathrm{~cm}$. Moisture release data were obtained after applying eight increasing pressures to soil cores from 0.1 to $400 \mathrm{kPa}$ using a pressure plate.

In the fall before planting, soil analyses were 
completed. The $\mathrm{pH}$ was adjusted to 6.5 at both sites with calcitic lime. Phosphorus (0-46-0) was applied to the-PFR site before planting to raise the level to that in the+PFR site. Potassium levels at the two sites were similar and adequate for crop growth.

Ten treatments were applied to both sites in a randomized complete block design with five replications. Plot size was 6.0 by $3.5 \mathrm{~m}$. Preplant amendments were applied uniformly over designated plots in May 1994 and incorporated to a depth of $20 \mathrm{~cm}$. Treatments were as follows: 1) untreated control; 2) metalaxyl (Ridomil2E; CIBA-GEIGY Corp., Greensboro, N.C.) applied to the soil in a 90-cm-wide weedfree planting strip at $0.4 \mathrm{~g} \cdot \mathrm{m}^{-2}$ a.i. on 10 Oct. 1994 and 23 Mar. 1995; 3 ) raised beds $25 \mathrm{~cm}$ tall $\times 75 \mathrm{~cm}$ wide constructed before planting; 4) phosphorous acid (fertilizer formulation, sodium and potassium phosphate, $54 \% \mathrm{w} / \mathrm{w}$, Wilber Ellis Corp., Fresno, Calif.) applied to runoff as a foliar spray at $0.4 \%$ (v:v) on 14 July, 15 Aug., 7 Oct. 1994, and 7 June, 7 July, and 8 Aug. 1995; 5) gypsum $\left(\mathrm{CaSO}_{4}\right.$; United States Gypsum Company, Chicago, Ill.) equivalent to $22.0 \%$ elemental calcium incorporated at $29 \mathrm{~kg} /$ plot (13.5 thha $\left.{ }^{-1}\right)$; 6) calcitic limestone (CaCO3; Seneca Stone Co., Fayette, N.Y.) preplant incorporated at $22 \mathrm{~kg}$ per plot (10.2 t.ha' $\left.\left.{ }^{-1}\right) ; 7\right)$ dolomitic limestone $\left(\mathrm{CaMg}\left[\mathrm{CO}_{3}\right]_{2}\right.$; Agway, Stanley, N.Y.) preplant incorporated at $13.8 \mathrm{~kg}$ perplot $\left.\left(6.4 \mathrm{t} \cdot \mathrm{ha}^{-1}\right) ; 8\right)$ brewery compost (AllGro, Hampton, N.H.) preplant incorporated at a rate of $\left.21.4 \mathrm{~kg} / \mathrm{plot}\left(10 \mathrm{t} \cdot \mathrm{ha}^{-1}\right) ; 9\right)$ Cornell University manure compost (Ithaca, N.Y.) preplant incorporated at the rate of $18.6 \mathrm{~kg}$ per plot (8.6 tha $\left.\mathrm{h}^{-1}\right)$; and 10) ammonium nitrate $\left(\mathrm{NH}_{4} \mathrm{NO}_{3}\right)(34-0-0)$ applied at the rate of 0.92 $\mathrm{kg} /$ plot $\left(150 \mathrm{~kg} \cdot \mathrm{ha}^{-1} \mathrm{~N}\right)$ in the planting year, equal to the reported amount of $\mathrm{N}$ applied in either compost treatment. This was provided in split applications, 25\% in July, 50\% in August, and $25 \%$ in September 1994.

Pathogen-free tissue-cultured plants of 'Heritage' primocane-fruiting red raspberry were planted on 6 June 1994. Plants were set at $1.0-\mathrm{m}$ in-row spacing in six-plant plots with $3.5 \mathrm{~m}$ between-row spacing, as a single row in the center of each treated area. Throughout the experiment, standard commercial cultural practices were applied uniformly to both sites (Pritts and Handley, 1989), except where noted.

Maintenance $\mathrm{N}$ fertilizer was not provided in the establishment year(1994). In the subsequent growing season, all plots were side-dressed with $500 \mathrm{~kg} \cdot \mathrm{ha}^{-1}$ calcium nitrate $\left(\mathrm{CaNO}_{3}\right)(15.5-0-0)$; $25 \%$ was applied on 1 May, $50 \%$ on 5 June, and $25 \%$ on 7 July. Tensiometers in each of the five control plots were used to monitor soil moisture levels. Drip irrigation was used for plant establishment, to maintain optimum soil moisture for plant growth throughout the growing season, and to saturate the soil to provide conditions conducive to disease development. In 1995, four drip-irrigated saturation periods were initiated on 16 June ( $24 \mathrm{~h}), 22$ June (72 h), 13 July (72 h), and 6 Sept. ( $24 \mathrm{~h}$ ) to extend the period of a saturating rainfall.

Simazine herbicide (Princep 90WDG; CibaGeigy Corp., Greensboro, N.C.) (3.7 kg $\cdot \mathrm{ha}^{-1}$ a.i.) was applied to all plots for pre-emergent weed control in the early spring of 1995 before primocane emergence. Sethoxydim herbicide (Poast 1.5EC; BASF Corp., $2 \mathrm{~kg} \cdot \mathrm{ha}^{-1}$ a.i.) was applied to all plots on 3 May 1995 to control surviving grassy weeds. All plots were also hand weeded in 1994 and 1995 to minimize raspberry plant and weed competition. After the first growing season, height was measured on the tallest cane from each of the original six plants per plot, and cane diameter was measured with a digital caliper micrometer $5 \mathrm{~cm}$ above the soil surface. The total number of canes in a $0.5-\mathrm{m}^{2}$ grid in the center of each plot was determined as a measure of cane density. All canes were cut off at the ground level during the dormant season, and then weight of the above-ground biomass was determined.

At the end of the second growing season (1995), heights and diameters were measured on 10 representative canes per plot, and the number of canes in a $0.5-\mathrm{m}^{2}$ grid in the center of each plot was counted as before. Total fruit yields in the +PFR site were obtained by harvesting the entire plot area for all replications of all 10 treatments. Since yields were much higher in the -PFR site, total fruit yields were estimated by harvesting a 1-m-long section in the center of each plot area and multiplying by the length of each plot. Average individual fruit weight was calculated from a running average of weight from a representative one-pint (about $400 \mathrm{~g}$ ) sample from each plot on each harvest date divided by the numbers of berries in the sample.

Data were analyzed using the SAS (SAS Institute, Cary, N.C.) general linear models procedure.

Field experiment 2 . Asecond field study was initiated in the +PFR site in May 1997 to further investigate various $\mathrm{Ca}$ and $\mathrm{S}$ amendments on PRR development. Seven treatments replicated five times were arranged in a randomized complete block design. Individual plots measured 5 $\mathrm{m}$ in length and $4 \mathrm{~min}$ width. Amendments were broadcast onto plots on 23 May and incorporated to a depth of $20 \mathrm{~cm}$. Treatments were 1) untreated control; 2) gypsum $\left(\mathrm{CaSO}_{4} \cdot 2\left[\mathrm{H}_{2} \mathrm{O}\right]\right)$ at a $1 \times$ rate $\left(13.6 \mathrm{t} \cdot \mathrm{ha}^{-1}\right)$, equivalent to $21 \%$ elemental $\mathrm{Ca}$ and $16 \%$ elemental $\mathrm{S}$ at $27 \mathrm{~kg} / \mathrm{plot}, 3$ ) gypsum at half this rate; 4) calcitic limestone $\left(\mathrm{CaCO}_{3}\right)$ at $\left.15.7 \mathrm{~kg} / \operatorname{plot}\left(7.95 \mathrm{t} \cdot \mathrm{ha}^{-1}\right) ; 5\right)$ calcium chloride $\left(\mathrm{CaCl}_{2}\right)$ at $17.4 \mathrm{~kg} /$ plot $\left.\left(8.8 \mathrm{t} \cdot \mathrm{ha}^{-1}\right) ; 6\right) 90 \%$ elemental sulfur (S) at $4.8 \mathrm{~kg} / \mathrm{plot}\left(2.4 \mathrm{t} \cdot \mathrm{ha}^{-1}\right)$; and 7) potassium sulfate $\left(\mathrm{K}_{2} \mathrm{SO}_{4}\right)$ at $23.9 \mathrm{~kg} / \mathrm{plot}$ (12.1 $\left.\mathrm{t}^{\cdot \mathrm{ha}^{-1}}\right)$. The total amount of elemental $\mathrm{Ca}$ applied in both the calcitic limestone and calcium chloride treatments was equal to that in the $1 \mathrm{x}$ gypsum treatment, which was designed to repeat the gypsum treatment in field experiment 1 . Similarly, the amount of elemental S supplied by the $90 \% \mathrm{~S}$ and potassium sulfate treatments equaled that supplied by the $1 \times$ gypsum treatment.

Five tissue-cultured 'Heritage' red raspberry plants were set $1 \mathrm{~m}$ apart in-row in the middle of each treated area on 29 May. Standard cultural practices were followed throughout the study (Pritts and Handley, 1989); pest management practices followed commercial guidelines (Pritts et al., 1997), although no fungicides that are active against PFR were applied.
Plant growth was assessed in October 1997, June and November 1998, and November 1999. Mother plant mortality was noted in the fall of the planting year and again the following spring. All above-ground growth in each plot was removed in October 1997, and total cane length (primary cane length plus branch length) and fresh weight were recorded. Whole-plot above-ground biomass, average cane height, primocane density, and height of the two tallest canes were determined in November 1998 and 1999. Yield data were collected in 1998 only. Entire plots were harvested every 2 to $3 \mathrm{~d}$ from 17 Aug. until 28 Sept. Average individual fruit weight was calculated from a running average of weight from a representative 1-pint (about 400-g) sample from each plot on each harvest date divided by the numbers of berries in the sample. Analysis of variance (SuperANOVA, Abacus Concepts, Berkeley, Calif.) was used to test the significance of differences among treatment means.

Greenhouse experiment. Field soil was collected from untreated control plots at the +PFR and -PFR sites in early February 1996. On 20 Feb. 1996, Phytophthora-free plants of 'Titan' red raspberry (tissue cultured by Nourse Farms, Whately, Mass.) were transplanted into pots containing $800 \mathrm{~mL}$ of a 2 vermiculite : 1 field soil mix (v/v). Treatments consisted of 1$)$ +PFR field soil; 2) -PFR field soil; 3) +PFR, + pasteurization; 4) $-\mathrm{PFR},+$ pasteurization; 5) +PFR, + fungicides; 6) -PFR, + fungicides; 7) +PFR, $+1 \times$ gypsum; 8 ) +PFR, $+4 \times$ gypsum; 9) +PFR, + 1× gypsum, + pasteurization; 10) + PFR, $+4 \times$ gypsum, + pasteurization.

Pasteurization was performed by heating soil with steam to $60{ }^{\circ} \mathrm{C}$ for $30 \mathrm{~min}$. Fungicide applications were made on 27 Feb. 1996. The fungicide treatment included both metalaxyland phosphorous acid applied in the same manner and rates as in the field experiment. Gypsum treatments were applied and mixed into soil from the +PFR site before transplanting, at rates of either $6.8 \mathrm{~g} \cdot \mathrm{L}^{-1}$ soil mix (equivalent to the $1 \times$ field rate) or $27.2 \mathrm{~g} \cdot \mathrm{L}^{-1}$ soil mix.

All plants were flooded for a $24-\mathrm{h}$ period on 7,18 , and 28 Mar., and for $48 \mathrm{~h}$ on $8 \mathrm{Apr}$. 1996 to create conditions favorable for infection. Plants were grown under 15 -h day lengths, and 18 to $20^{\circ} \mathrm{C}$ daytime and 16 to $18^{\circ} \mathrm{C}$ night temperatures.

Plant height was measured on $22 \mathrm{Apr}$. and 13 May 1996. Presence of above-ground disease symptoms was recorded on 22 and $30 \mathrm{Apr}$. and 13 May 1996.Above-ground disease symptoms included stunting of the terminal apex, scorching of foliage, wilting of foliage, and stem lesions near the soil surface.

Each treatment was replicated six times. Data were analyzed as a CRD using specific orthogonal and nonorthogonal treatments and tested for significance of linear contrasts using SAS general linear models (SAS Institute, Cary, N.C.).

\section{Results}

Field experiment 1 . Soil core samples from the +PFR and the -PFR sites did not differ significantly in bulk density (means $=1.27$ 
and $1.26 \mathrm{~g} \cdot \mathrm{cm}^{-3}$, respectively) or moisture retention properties.

In the establishment year, large growth differences were apparent between the +PFR and the-PFR sites (Table 1). Although these cannot be compared statistically because the sites were not replicated, when averaged across all ten treatments per site, the -PFR site had greater measures for cane height ( $63.6 \mathrm{vs} .39 .7 \mathrm{~cm})$, cane diameter ( 8.1 vs. $5.2 \mathrm{~mm}$ ), average cane density (6.1 vs. 0.7 canes $/ \mathrm{m}^{2}$ ), and dormant cane biomass $(0.38$ vs. $0.07 \mathrm{~kg} / \mathrm{plot})$. Above-ground symptoms of Phytophthora were not observed, despite poor growth in the + PFR site.

In the-PFR plots, plants in all treatments grew relatively well, although cane height and diameter were lowest in the phosphorous acid and brewery compost treatments. Although typical above-ground PRR symptoms did not develop at the +PFR site, presumably due to the dry year, plant growth was extremely variable and poor overall. Plots treated with dolomitic lime had the highest cane density and pruning weight, and plots treated with phosphorous acid had the second highest cane density and pruning weight at the end of the planting year. Although these increases are not statistically significant from the control due to plot variability, they represent a $79 \%$ and $71 \%$ increase in cane density respectively, and a $37 \%$ and $17 \%$ increase in dormant cane biomass compared with untreated control plants. Plants treated with brewery and manure compost had the shortest cane heights and smallest cane diameters, $26 \%$ and $11 \%$ shorter canes and $21 \%$ and $15 \%$ smaller cane diameters than the control,

Table 1. Effect of soil amendments on establishment-year (1994) growth of 'Heritage' red raspberry grown in a Phytophthora fragariae var. rubi-infested (+PFR) and noninfested (-PRF) field in Ithaca, N.Y.

\begin{tabular}{lllll}
\hline Treatment & $\begin{array}{c}\text { Cane } \\
\mathrm{ht} \\
(\mathrm{cm})\end{array}$ & $\begin{array}{l}\text { Cane } \\
\text { diam } \\
(\mathrm{mm})\end{array}$ & $\begin{array}{c}\text { Cane } \\
\text { no. } \\
\left(\mathrm{m}^{2}\right)\end{array}$ & $\begin{array}{c}\text { Cane } \\
\text { biomass } \\
\text { (kg/plot })\end{array}$ \\
\hline Pathogen infested site (+PFR) & & & & \\
Calcitic lime & 50.8 & 5.83 & 0.45 & 0.064 \\
Dolomitic lime & 45.1 & 5.54 & 1.25 & 0.112 \\
Raised bed & 42.4 & 5.59 & 0.25 & 0.038 \\
Phosphorous acid & 41.8 & 5.04 & 1.20 & 0.096 \\
Gypsum & 41.7 & 5.29 & 0.65 & 0.084 \\
Ammonium nitrate & 40.5 & 5.19 & 1.05 & 0.086 \\
Untreated control & 38.0 & 5.35 & 0.70 & 0.082 \\
Ridomil & 35.2 & 5.02 & 0.40 & 0.064 \\
Manure compost & 33.9 & 4.53 & 0.45 & 0.042 \\
Brewery compost & 28.2 & 4.23 & 0.75 & 0.046 \\
Site average & 39.7 & 5.16 & 0.715 & 0.071 \\
LSD & 13.8 & 1.36 & 1.06 & 0.072 \\
$P$ value & 0.12 & 0.41 & 0.54 & 0.48 \\
Pathogen free site (-PFR) & & & & \\
Calcitic lime & $71.5 \mathrm{a}$ & $8.75 \mathrm{abc}$ & 5.70 & 0.384 \\
Manure compost & $70.6 \mathrm{a}$ & $9.35 \mathrm{a}$ & 6.80 & 0.464 \\
Ammonium nitrate & $69.6 \mathrm{a}$ & $9.01 \mathrm{ab}$ & 9.35 & 0.484 \\
Dolomitic Lime & $65.7 \mathrm{a}$ & $7.96 \mathrm{bcde}$ & 7.05 & 0.428 \\
Raised bed & $64.8 \mathrm{ab}$ & $8.40 \mathrm{abcd}$ & 4.50 & 0.340 \\
Ridomil & $64.5 \mathrm{ab}$ & $7.94 \mathrm{bcde}$ & 4.65 & 0.360 \\
Untreated Control & $64.4 \mathrm{ab}$ & $8.11 \mathrm{abcde}$ & 5.75 & 0.328 \\
Gypsum & $61.5 \mathrm{abc}$ & $7.65 \mathrm{cde}$ & 5.50 & 0.344 \\
Phosphorous acid & $52.6 \mathrm{bc}$ & $7.24 \mathrm{de}$ & 5.15 & 0.328 \\
Brewery compost & $51.1 \mathrm{c}$ & $7.02 \mathrm{e}$ & 6.55 & 0.374 \\
Site average & 63.6 & 8.14 & 6.10 & 0.383 \\
LSD & 12.9 & 1.36 & 5.18 & 0.21 \\
$P$ value & 0.03 & 0.02 & 0.77 & 0.79 \\
\hline
\end{tabular}

${ }^{2}$ Means within a column followed by a common letter are not statistically different according to Fisher's protected LSD test $(P<0.05)$. respectively. Differences in cane height of the brewery compost versus limestone treatments were significant at $P<0.05$ when individual treatments were compared (Table 1 ).

At the end of the second growing season (1995), cane height treatment means ranged from 63.2 to $83.6 \mathrm{~cm}$ in the +PFR plots compared to 103 to $118 \mathrm{~cm}$ in the -PFR plots. For these same respective comparisons, cane diameter means ranged from 6.2 to 8.7 vs. 7.7 to $8.7 \mathrm{~mm}$, and cane density means ranged from 15.6 to 35.6 vs. 55.6 to 70.4 canes $/ \mathrm{m}^{2}$. Relative to plants in the infested site, those in the uninfested field site had, on average, $46 \%$ taller canes, 9\% larger cane diameters, $145 \%$ more canes per $\mathrm{m}^{2}$ (Table 2) and $57 \%$ greater fruit yield (Table 3 ).

In the +PFR site, there were few statistically significant differences between treatments for plant growth or yield as plots were extremely variable. Plants in the raised bed and gypsum treatments had the tallest canes, $15 \%$ and $14 \%$ taller, respectively, than the untreated control. Plants in the raised bed treatment had cane diameters $26 \%$ greater than the control $(P<$ 0.05 ). Brewery compost and manure composttreated plants had the lowest cane heights and diameters. Plants in the calcitic lime, ammonium nitrate and gypsum treatments had the highest cane densities $(37 \%, 23 \%$, and $17 \%$ higher than the control, respectively) (Table 2). Total fruit yield was highest in the phosphorous acid and gypsum-treated plots. Even though the differences were not significant at $P<0.05$, phosphorous acid had a $52 \%$ greater yield and gypsum had a $48 \%$ greater yield compared to the control, and a $29 \%$ and $24 \%$ increase in yield, respectively, compared to the standard commercial fungicide, metalaxyl. Manure compost and brewery compost had the lowest fruit yield, $32 \%$ and $24 \%$ less than the control. Ridomil and raised bed treatments resulted in statistically larger fruit size compared to the control (Table 3).

Field experiment 2. Plants grown in infested soil receiving gypsum or calcitic lime exhibited the greatest growth and had 2 to 3 times the yield of plants in unamended plots (Tables 4 and 5). In contrast, calcium chloride had a deleterious effect on plant growth, as $80 \%$ of the plants did not survive this treatment.

Table 2. Effect of soil amendments on plant growth of 'Heritage' red raspberry in 1995 (Year 2) grown in a Phytophthora fragariae var. rubi-infested (+PFR) and noninfested (-PRF) field in Ithaca, N.Y.

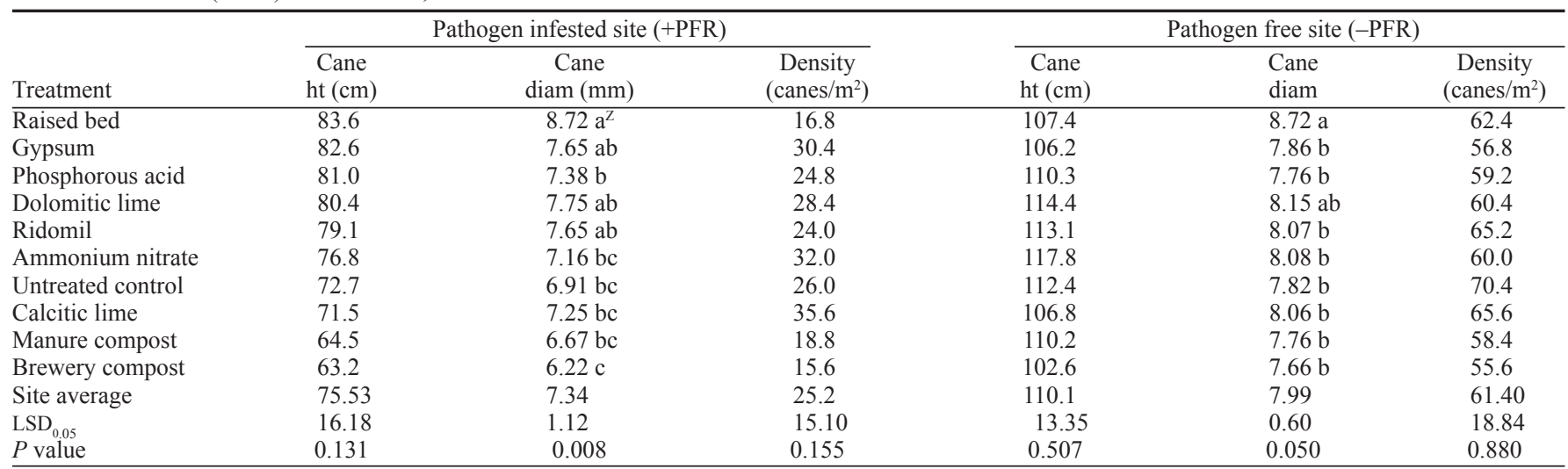

${ }^{2}$ Means within a column followed by a common letter are not statistically different according to Fisher's protected LSD test $(P<0.05)$. 
Plants growing in sulfur-amended plots were similar to unamended plots for all measured variables.

Greenhouse experiment. The pasteurization, $1 \times$ gypsum, and fungicide treatments increased plant height by $39 \%, 40 \%$, and $61 \%$ relative to the untreated control, respectively, when plants were grown in +PFR soil, and these differences were all statistically significant (Tables 5 and 6). Similarly, plants grown in + PFR + pasteurization $+1 \times$ gypsum were more than twice as tall as plants grown in + PFR alone, whereas the combined effect of these two factors was reduced substantially when the gypsum was increased to $4 \times$ (Table 6). Plants treated with fungicides were significantly taller than untreated plants in both infested and uninfested soil (Tables 6 and 7).

On 30 Apr. 1996 (69 d after transplanting), $100 \%$ of the plants grown in untreated + PFR soil had foliar symptoms of root rot, whereas only $17 \%$ of plants grown in +PFR with gypsum at $1 \times$ or $4 \times$ were symptomatic (Table 6 ). At the end of the experiment (13 May 1996), 100\% of the plants grown in +PFR soil still exhibited foliar disease symptoms, whereas $33 \%$ of plants grown in + PFR soil with gypsum at $1 \times$ or $4 \times$ had foliar disease symptoms. None of the plants in the sterilized soil or in fungicide-treated soil exhibited disease symptoms,

Table 3. Effect of soil amendments on fruiting traits of 'Heritage' red raspberry in 1995 (Year 2) grown in a Phytophthora fragariae var. rubi-infested (+PFR) and noninfested (-PRF) field in Ithaca, N.Y.

\begin{tabular}{|c|c|c|c|c|}
\hline \multirow[b]{2}{*}{ Treatment } & \multicolumn{2}{|c|}{ Pathogen infested site (+PFR) } & \multicolumn{2}{|c|}{ Pathogen free site (-PFR) } \\
\hline & Yield $\left(\mathrm{g} \cdot \mathrm{m}^{-1}\right)$ & Fruit size $(\mathrm{g})$ & Yield $\left(\mathrm{g} \cdot \mathrm{m}^{-1}\right)$ & Fruit size $(\mathrm{g})$ \\
\hline Phosphorous acid & $1218 a^{z}$ & $1.63 a b c$ & 1033 & 1.44 \\
\hline Gypsum & $1174 \mathrm{a}$ & $1.55 \mathrm{bcd}$ & 1656 & 1.34 \\
\hline Ridomil & $944 a b$ & $1.65 \mathrm{ab}$ & 1589 & 1.43 \\
\hline Dolomitic lime & $933 a b$ & $1.51 \mathrm{~d}$ & 1482 & 1.34 \\
\hline Untreated control & $800 a b$ & $1.54 \mathrm{~cd}$ & 1291 & 1.43 \\
\hline Ammonium nitrate & $794 \mathrm{ab}$ & $1.49 \mathrm{~d}$ & 1544 & 1.34 \\
\hline Raised bed & $779 a b$ & $1.72 \mathrm{a}$ & 1437 & 1.33 \\
\hline Calcitic lime & $729 a b$ & $1.53 \mathrm{~cd}$ & 1259 & 1.38 \\
\hline Manure compost & $604 \mathrm{~b}$ & $1.58 \mathrm{bcd}$ & 1270 & 1.48 \\
\hline Brewery compost & $541 \mathrm{~b}$ & $1.54 \mathrm{~cd}$ & 776 & 1.39 \\
\hline Site average & 852 & 1.57 & 1334 & 1.39 \\
\hline $\mathrm{LSD}_{0.05}$ & 554 & 0.10 & 599 & 0.19 \\
\hline$P$ value & 0.03 & 0.001 & 0.130 & 0.783 \\
\hline
\end{tabular}

${ }^{2}$ Means followed by a common letter are not statistically different according to Fisher's protected LSD test $(P<0.05)$.

\section{Discussion}

Climatic conditions during field experiment 1 were atypically dry and not conducive to PRR development, particularly for a moderately susceptible cultivar like Heritage. Total precipitation for the 14-month period (September 1994 through October 1995) was $200 \mathrm{~mm}$ below normal (Northeast Regional Climate Center, Ithaca, N.Y.). Nevertheless, when averaged across all treatments, plants in the -PFR site were $144 \%$ more dense and $58 \%$ higher yielding than those in the +PFR site, despite the absence of typical aboveground symptoms of PRR in the latter. Soil bulk density and moisture retention properties were the same for both sites, suggesting that differences in plant response were likely due to biological factors. This was further confirmed by the positive response to pasteurization of + PFR soil. It is likely that these differences resulted from sublethal levels of root infection caused by $P$. fragariae var. rubi, as evidenced by the positive response of potted plants grown in +PFR soil to metalaxyl and phosphorous acid, two fungicides with specificity against Oomycete pathogens.

Raised bed culture of Rubus spp. has been recommended for PPR control (Heiberg, 1995; Maloney et al., 1993; Wilcox, 1999b). However, in our study, raised bed culture did not produce significant second year yield increases compared to the untreated control plants in infested soil. Even though plants on raised

Table 4. Effect of various calcium and sulfur-based amendments on survival, growth and yield of 'Heritage' red raspberry planted in a site infested with Phytophthora fragariae var. rubi in Ithaca, N.Y., in 1997.

\begin{tabular}{|c|c|c|c|c|c|}
\hline \multirow[b]{3}{*}{ Treatment } & \multirow{2}{*}{\multicolumn{2}{|c|}{ Rate }} & \multicolumn{3}{|c|}{ October 1997} \\
\hline & & & \multirow{2}{*}{$\begin{array}{c}\text { End-of-season } \\
\text { survival } \\
(\%)\end{array}$} & \multirow{2}{*}{$\begin{array}{c}\text { Total } \\
\text { primocane } \\
\text { length } \\
\left(\mathrm{m} \cdot \mathrm{m}^{-2}\right)\end{array}$} & \multirow{2}{*}{$\begin{array}{c}\text { Dormant } \\
\text { pruning } \\
\text { wt } \\
\left(\mathrm{kg} \cdot \mathrm{m}^{-2}\right)\end{array}$} \\
\hline & $\begin{array}{c}\mathrm{Ca}^{\mathrm{y}} \\
\left(\mathrm{kg} \cdot \mathrm{ha}^{-1}\right)\end{array}$ & $\begin{array}{c}\mathrm{S}^{\mathrm{y}} \\
\left(\mathrm{kg} \cdot \mathrm{ha}^{-1}\right)\end{array}$ & & & \\
\hline Calcitic lime & 2803 & 0 & $100 \mathrm{a}^{\mathrm{z}}$ & $1.35 \mathrm{a}$ & $0.097 \mathrm{a}$ \\
\hline Gypsum $(0.5 \times)$ & 1401 & 1077 & $100 \mathrm{a}$ & $1.34 \mathrm{a}$ & $0.092 \mathrm{ab}$ \\
\hline Gypsum (1.0×) & 2803 & 2153 & $100 \mathrm{a}$ & $1.14 \mathrm{ab}$ & $0.074 \mathrm{abc}$ \\
\hline Untreated control & 0 & 0 & $100 \mathrm{a}$ & $0.83 \mathrm{~b}$ & $0.056 \mathrm{bc}$ \\
\hline Potassium sulfate & 0 & 2153 & $92 \mathrm{a}$ & $1.16 \mathrm{ab}$ & $0.073 \mathrm{abc}$ \\
\hline Sulfur & 0 & 2153 & $100 \mathrm{a}$ & $0.82 \mathrm{~b}$ & $0.044 \mathrm{~cd}$ \\
\hline Calcium chloride & 2803 & 0 & $20 \mathrm{~b}$ & $0.24 \mathrm{c}$ & $0.014 \mathrm{~d}$ \\
\hline $\mathrm{LSD}_{0,05}$ & & & 12.6 & 0.50 & 0.041 \\
\hline$P$ value & & & $<0.001$ & 0.001 & 0.004 \\
\hline
\end{tabular}

${ }^{2}$ Means within a column followed by a common letter are not statistically different according to Fisher's Protected LSD test $(P<0.05)$.

Table 5. Effect of various calcium and sulfur-based amendments on survival, growth and yield of 'Heritage' red raspberry planted in a site infested with Phytophthora fragariae var. rubi in Ithaca, N.Y. in 1997.

\begin{tabular}{|c|c|c|c|c|c|c|c|}
\hline \multirow[b]{3}{*}{ Treatment } & \multirow{2}{*}{\multicolumn{3}{|c|}{ June 1998}} & \multicolumn{2}{|c|}{ November 1998} & \multirow{2}{*}{\multicolumn{2}{|c|}{1998}} \\
\hline & & & & \multirow[b]{2}{*}{$\begin{array}{c}\text { Cane } \\
\text { density } \\
\left(\text { canes } / \mathrm{m}^{2}\right)\end{array}$} & \multirow{2}{*}{$\begin{array}{c}\text { Dormant } \\
\text { pruning } \\
\mathrm{wt} \\
\left(\mathrm{kg} \cdot \mathrm{m}^{-2}\right)\end{array}$} & & \\
\hline & $\begin{array}{c}\text { Survival } \\
(\%)\end{array}$ & $\begin{array}{c}\text { Cane } \\
\text { ht } \\
(\mathrm{cm})\end{array}$ & $\begin{array}{c}\text { Cane } \\
\text { density } \\
\left(\text { canes } / \mathrm{m}^{2}\right)\end{array}$ & & & $\begin{array}{c}\text { Fruit } \\
\text { size } \\
\text { (g/berry) }\end{array}$ & $\begin{array}{c}\text { Yield } \\
\left(\mathrm{g} \cdot \mathrm{m}^{-1}\right)\end{array}$ \\
\hline Calcitic lime & $100 \mathrm{a}^{\mathrm{z}}$ & $47.8 \mathrm{ab}$ & $35.6 \mathrm{a}$ & $17.2 \mathrm{a}$ & $0.314 \mathrm{ab}$ & 2.03 & $649 \mathrm{abc}$ \\
\hline Gypsum $(0.5 \times)$ & $100 \mathrm{a}$ & $51.3 \mathrm{a}$ & $20.0 \mathrm{~b}$ & $14.8 \mathrm{a}$ & $0.358 \mathrm{a}$ & 2.14 & $875 \mathrm{a}$ \\
\hline Gypsum $(1.0 \times)$ & $100 \mathrm{a}$ & $49.7 \mathrm{a}$ & $24.6 \mathrm{ab}$ & $15.8 \mathrm{a}$ & $0.346 \mathrm{a}$ & 2.09 & $698 \mathrm{ab}$ \\
\hline Untreated & $100 \mathrm{a}$ & $35.4 \mathrm{~b}$ & $14.0 \mathrm{bc}$ & $8.4 \mathrm{~b}$ & $0.149 \mathrm{c}$ & 2.05 & $289 \mathrm{~cd}$ \\
\hline Sulfur & $96 \mathrm{a}$ & $42.9 \mathrm{ab}$ & $15.6 \mathrm{bc}$ & $8.4 \mathrm{~b}$ & $0.165 \mathrm{c}$ & 2.09 & $453 \mathrm{bcd}$ \\
\hline Potassium.sulfate & $92 \mathrm{a}$ & $46.0 \mathrm{ab}$ & $15.4 \mathrm{bc}$ & $7.8 \mathrm{~b}$ & $0.183 \mathrm{bc}$ & 2.11 & $432 \mathrm{bcd}$ \\
\hline Calcium.chloride & $20 \mathrm{~b}$ & $20.1 \mathrm{c}$ & $4.8 \mathrm{c}$ & $1.2 \mathrm{c}$ & $0.052 \mathrm{~d}$ & 2.12 & $91 \mathrm{~d}$ \\
\hline $\mathrm{LSD}_{005}$ & 12.9 & 14.2 & 12.1 & 6.2 & 0.137 & 0.17 & 409 \\
\hline$P$ value & $<0.001$ & 0.002 & 0.001 & $<0.001$ & $<0.001$ & 0.818 & 0.011 \\
\hline
\end{tabular}

y Incorporated to a depth of $20 \mathrm{~cm}$.

${ }^{z}$ Means within a column followed by a common letter are not statistically different according to Fisher's protected LSD test $(P<0.05)$. 
Table 6. Effect of soil pasteurization, fungicide, and gypsum amendment on the development of phytophthora root rot (PRR) symptoms in greenhouse-grown 'Titan' red raspberry plants.

\begin{tabular}{|c|c|c|c|c|c|c|c|c|c|}
\hline \multirow{2}{*}{$\begin{array}{l}\text { Treatment } \\
\text { no. }\end{array}$} & \multirow[b]{2}{*}{$\mathrm{PFR}^{\mathrm{z}}$} & \multirow[b]{2}{*}{ Pasteurization ${ }^{y}$} & \multirow[b]{2}{*}{ Fungicide $^{\mathrm{x}}$} & \multirow[b]{2}{*}{ Gypsum $^{w}$} & \multicolumn{2}{|c|}{ Avg ht (cm) } & \multicolumn{3}{|c|}{ Plants with PRR symptoms (\%) } \\
\hline & & & & & 22 Apr. 1996 & 13 May 1996 & 22 Apr. 1996 & 30 Apr. 1996 & 13 May 1996 \\
\hline 1 & + & - & - & - & 18.7 & 17.8 & 83 & 100 & 100 \\
\hline 2 & - & - & - & - & 18.0 & 19.7 & 0 & 0 & 0 \\
\hline 3 & + & + & - & - & 21.0 & 24.8 & 0 & 0 & 0 \\
\hline 4 & - & + & - & - & 17.2 & 20.7 & 0 & 0 & 0 \\
\hline 5 & + & - & + & - & 24.2 & 28.7 & 0 & 0 & 0 \\
\hline 6 & - & - & + & - & 24.0 & 29.2 & 0 & 0 & 0 \\
\hline 7 & + & - & - & $1 \times$ & 23.0 & 25.0 & 17 & 17 & 33 \\
\hline 8 & + & - & - & $4 \times$ & 20.3 & 20.7 & 0 & 17 & 33 \\
\hline 9 & + & + & - & $1 \times$ & 29.8 & 38.3 & 0 & 0 & 0 \\
\hline 10 & + & + & - & $4 \times$ & 22.8 & 25.8 & 0 & 0 & 0 \\
\hline
\end{tabular}

${ }^{\mathrm{z}}(+)$ PFR indicates that soil from a Phytophthora fragariae var. rubi-infested field and (-) PFR indicates soil from an uninfested field.

${ }^{y}$ Soil was heat-treated with steam at $60{ }^{\circ} \mathrm{C}$ for $30 \mathrm{~min}$ before planting.

xpotted plants were treated with both metalaxyl to soil and phosphorous acid to leaves before flooding.

${ }^{\mathrm{w}} 1 \times$ rate is $6.8 \mathrm{~g} \cdot \mathrm{L}^{-1}$ soil mix.

Table 7. Significance of linear contrasts among treatments from Table 6 .

\begin{tabular}{lccc}
\hline & & \multicolumn{2}{c}{ Plant ht $(P$ value $)$} \\
\cline { 3 - 4 } Effect & Contrast & 22 Apr. & 13 May \\
\hline Infestation & 1 vs. 2 & NS & NS \\
Fungicide & 1 vs. 5 & 0.025 & 0.002 \\
Fungicide & 2 vs. 6 & 0.015 & 0.006 \\
Fungicide & 1,2 vs. 5, 6 & 0.001 & 0.0001 \\
Sterilization & 1 vs. 3 & NS & 0.0391 \\
Sterilization & 7,8 vs. 9,10 & 0.008 & 0.0003 \\
Gypsum & 1 vs. 7 & 0.074 & 0.035 \\
Gypsum & 1 vs. 8 & NS & NS \\
Gypsum & 9 vs. 10 & 0.005 & 0.0004 \\
\hline NSNonsignificant at $P<0.05$ & &
\end{tabular}

beds produced the greatest cane height and diameter, yields were atypically low. In a previous study at this site (Wilcox 1999b), raised beds provided a significant yield increase for the relatively resistant cultivar Newburgh, but not the highly susceptible cultivar Titan. The susceptibility of cv. Heritage is intermediate between these two (Wilcox, 1999a). Thus, it is possible that the degree of control provided by raised beds was not sufficient to overcome the inherent susceptibility of 'Heritage' plants. Alternately, it is possible that plants on raised beds were more stressed during dry weather, particularly those with sublethal root infection, reducing yields compared to more normal years. Significant yield differences on raised beds in a pathogen-infested site were not achieved until year 3 of a previous study (Maloney et al., 1993). If raised beds are used for Phytophthora management, then particular attention may need to be paid to maintaining adequate soil moisture to avoid plant stress, particularly during dry years.

The foliar treatment of phosphorous acid produced the greatest total fruit yield at the +PFR site. In plant tissues, fosetyl-Al, the active ingredient in Aliette fungicide, degrades to phosphorous acid $\left(\mathrm{H}_{3} \mathrm{PO}_{3}\right)$ (Coffey and Bower, 1984). Phosphorous acid dips, foliar sprays, or trunk injections were successful in controlling $P$. cinnamomi in avocado and pineapple [Ananas comosus (L.) Merr] (Pegg et al., 1990); P. palmivora in cocoa (Anderson and Guest, 1990; Holderness, 1990); P. cambivora in almond (Prunus amygdalus Batsch) and cherry (Prunus avium L.) (Wicks and Hall, 1990); and P. cactorum in peach (Prunus persica L. Batsch), apricot (Prunus armeniaca L.) (Lim et al., 1990) and strawberry (Ellis et al., 1998). Thus, our results support findings in other studies of successful control of multiple phytophthora diseases with $\mathrm{H}_{3} \mathrm{PO}_{3}$.

Many laboratory and greenhouse experiments have documented the role of $\mathrm{Ca}^{++}$in the infection sequence of phytophthora diseases (Deacon and Donaldson, 1993; Donaldson and Deacon, 1993; Hill et al., 1998; Morris and Gow, 1993; von Broembsen and Deacon, 1997; Warburton and Deacon, 1998; Xu-Chang and Morris, 1998). Soil supplementation with calcium interferes with zoospore functioning by restricting the liberation and movement of those infective propagules, and thus may reduce disease (Xu-Chang and Morris, 1998; von Broembsen and Deacon, 1997).

In our field study, preplant gypsum treatments produced a $48 \%$ higher yield than the control on the +PFR site, and a $24 \%$ higher yield than the metalaxyl fungicide treatment, an industry standard. Although differences among treatments often were not statistically significant due to plot variability, our second field study confirmed the beneficial effects of certain calcium amendments on PRR suppression. Furthermore, repeating some of the treatments in the greenhouse confirmed the positive effect of gypsum in suppressing PRR in raspberries. In the greenhouse, incorporated gypsum provided disease control in infested, unsterilized soil, nearly comparable to that of the fungicide treatment. The deleterious effect of the calcium chloride amendment on plant survival and growth was due to the high salt index of this material.

We did not observe a consistent effect of lime on plant performance in field experiment 1 , possibly because ground limestone may not provide an immediate release of sufficient free calcium cations. Time is required for the limestone to degrade into small particles that allow for cation dissociation, particularly in dry years. Primocane density seemed to be increased with lime amendment, but yields were intermediate. In field experiment 2 , the lime amendment exhibited a clear positive effect on plant growth (Tables 4 and 5), perhaps because of more rain during that year.

A soil $\mathrm{pH}$ of 6.0 to 6.5 was optimal for sporangium production by $P$. cinnamomi (Weste,
1983). In our study, there was no clear effect on disease development of soil $\mathrm{pH}$ in the high lime treatment (7.5 vs. 6.5), although high soil $\mathrm{pH}$ is known to increase the severity of disease caused by some Phytophthora spp. (Schmitthenner and Cannaday, 1983).

Ammonium nitrate-treated plants produced the tallest canes at the-PFR site. Nitrogen application generally promotes increased growth over plants grown under similar conditions without nitrogen (Smolarz et al.,1982), but we did not see increased plant growth or fruit yield with ammonium nitrate on plants in the +PFR site. Although nitrogen form can affect plant disease (Huber and Watson, 1974), there was no disease suppression from this treatment in our experiments. This is consistent with research on apple seedlings where ammonium nitrate had no effect on Phytophthora cactorum (McIntosh, 1972). Plants in phytophthora-infested sites may not have the capacity to respond to $\mathrm{N}$ fertilization, as they apparently are able to do in pathogen-free sites (Tables 1 and 2).

Brewery and manure compost treatments appeared to have long-term negative effects on plant growth and fruit yield at both the infested and uninfested sites. In almost all cases, compost treatments produced the lowest plant growth and fruit yield. Although the reasons for this are not clear, the compost may have contained a phytotoxic component. In the + PFR site, the moisture retention properties of the compost also may have improved conditions for disease development.

The benefits from a combination of gypsum and metalaxyl fungicide for treating Phytophthora are likely to be additive since each has a different mode of action. Gypsum has provided beneficial results in other studies on disease suppression (Stoltz, 1982; von Broembsen and Deacon, 1997; Menge et al., 1994), and may have broad effects on disease development as it was suppressive to Pythium in tomatoes as well (Gill, 1972).

Fungicide use and raised beds have been standard methods for controlling phytophthora root rot in raspberries. Our study suggests that a gypsum amendment, and perhaps other sources of calcium, may complement fungicides and raised beds in providing an integrated management strategy for this disease where it occurs. 


\section{Literature Cited}

Anderson, R.D. and D.I. Guest. 1990. The control of black pod, canker and seedling blight of cocoa caused by Phytophthora palmivora, with potassium phosphonate. Australasian Plant Pathol. 19:127-129.

Bristow, P.R. and G.E. Windom. 1992. The effect of sodium tetrathiocarbonate and fosetyl-Al in controlling phytophthora root rot of red raspberry in the Pacific Northwest. Phytopathology 82:1132 (abstr.).

Broadbent, P. and K.F. Baker. 1974. Behavior of Phytophthora cinnamomi in soils suppressive and conducive to root rot. Austral. J. Agr. Res. 25:121-137.

Carris, L.M. and P.R. Bristow. 1987. Absorption and translocation of metalaxyl in cabbage, red raspberry, and strawberry. J. Agr. Food Chem. 35:851-855.

Caruso, F.L. and W.F. Wilcox. 1990. Phytophthora cinnamomi as a cause of root rot and dieback of cranberry in Massachusetts. Plant Dis. 74:664-667.

Coffey, M.D. and L.A. Bower. 1984. In vitro variability among isolates of eight Phytophthora species in response to phosphorous acid. Phytopathology 74:738-742.

Converse, R.H. and C.D. Schwartze. 1968. A root rot of red raspberry caused by Phytophthora erythroseptica. Phytopathology 58:56-59.

Deacon, J.W. and S.P. Donaldson. 1993. Molecular recognition in the homing responses of zoosporic fungi, with special reference to Pythium and Phytophthora. Mycol. Res. 97:1153-1171.

Donaldson, S.P. and J.W. Deacon. 1993. Changes in motility of Pythium zoospores induced by calcium and calcium-modulating drugs. Mycol. Res. 97:877-883.

Duncan, J.M., D.M. Kennedy, and E. Seemuller. 1987. Identities and pathogenicities of Phytophthora spp. causing root rot of red raspberry. Plant Pathol. 36:276-289.

Ellis, M.A., D.C. Ferree, and L.V. Madden. 1986. Evaluation of metalaxyl and captafol soil drenches, composted hardwood bark soil amendments, and graft union placement on control of apple collar rot. Plant Dis. 70:24-26.

Ellis, M.A., W.F. Wilcox, and L.V. Madden. 1998 Efficacy of metalaxyl, fosetyl-Al, and straw mulch for control of strawberry leather rot, caused by Phytophthora cactorum. Plant Dis. 82:329-332.

Gill, D.L. 1972. Effect of gypsum and dolomite on Pythium diseases of seedlings. J. Amer. Soc. Hort. Sci. 97:467-471.

Graberg, M. 1994. Raspberry root rot in Sweden. Vaxtskyddsnotiser 58:116-117.

Heiberg, N. 1995. Control of root rot of red raspberries caused by Phytophthora fragariae var. rubi. Plant Pathol. 44:153-159.

Hill, A.E., D.E. Grayson, and J.W. Deacon. 1998. Suppressed germination and early death of Phytophthora infestans sporangia caused by pectin, inorganic phosphate, ion chelators and calcium-modulating treatments. European $\mathrm{J}$ Plant Pathol. 104:367-376.

Holderness, M. 1990. Efficacy of neutralised phosphonic acid (phosphorous acid) against Phytophthora palmivora pod rot and canker of cocoa. Australasian Plant Pathol. 19:130-131.

Huber, D.M. and Watson, R.D. 1974. Nitrogen form and plant disease. Annu. Rev. Phytopathol. 12:139-165.

Ilieva, E., F.X. Arulappan, and R. Pieters. 1995. phytophthora root and crown rot of raspberry in Bulgaria. European J. Plant Pathol. 101:623-626.

Kennedy, D.M. and J.M. Duncan. 1995. A papillate Phytophthora species with specificity to Rubus. Mycol. Res. 99:57-68.

Latorre, B.A. and R. Munoz. 1993. Root rot of red raspberry caused by Phytophthora citricola and Phytophthora citrophthora in Chile. Plant Dis. 77:715-718.

Lim, T.M., P.H. Jerie, and P.R. Merriman. 1990. Evaluation of phosphonic (phosphorous) acid for controlling phytophthora crown and trunk rot of peach and apricot. Australasian Plant Pathol. 19:134-136.

Maloney, K.E., W.F. Wilcox, and J.C. Sanford. 1993. Raised beds and metalaxyl for controlling phytophthora root rot of raspberry. HortScience 28:1106-1108.

McIntosh, D.L. 1972. Effects of soil water suction, soil temperature, carbon and nitrogen amendments, and host rootlets on survival in soils of zoospores of Phytophthora cactorum. Can. J. Bot. 50:269-272.

Menge, J.A., H.D. Ohr, E.L.V. Johnson, S. Campbell, F. Guillemet, N. Grech, and E. Pond. 1994. The effect of mulches, gypsum and fungicides on the performance of avocado planted in soil with Phytophthora cinnamomi and Phytophthora citricola. Phytopathology 84:1103 (abstr.).

Merwin, I.A., W.F. Wilcox, and W.C. Stiles. 1992. Influence of orchard ground cover management on the development of phytophthora crown and root rots of apple. Plant Dis. 76:199-205.

Messenger-Routh, B.J., J.A. Menge, and E.C. Pond. 1996. Effect of gypsum soil amendments on avocado root rot. Phytopathology 86:S30 (abstr.).

Morris, B.M. and N.A.R. Gow. 1993. Mechanism of electrotaxis of zoospores of phytopathogenic fungi. Phytopathology 83:877-882.

Nemec, S. and O. Lee. 1995. Management of phytophthora root and crown rot and blight of citrus with soil amendments. Phytopathology 85:1200 (abstr.).

Pegg, K.G., A.W. Whiley, and P.A. Hargreaves. 1990. Phosphonic (phosphorous) acid treatments control Phytophthora diseases in avocado and pineapple. Australasian Plant Pathol. 19:122-124.

Pritts, M. and D. Handley. 1989. Bramble production guide. Nat. Resour. Agr. Eng. Serv.-35, Ithaca, N.Y

Pritts, M., J. Kovach, G. English-Loeb, and W. Wilcox. 1997. Pest management recommendations for small fruit crops. Cornell Univ.,
Ithaca, N.Y.

Schmitthenner, A.F. and C.H. Cannaday. 1983. Role of chemical factors in development of Phytophthora diseases, p.189-198. In: D.C. Irwin, S. Bartnicki-Garcia, and P.H. Tsao (eds.). Phytophthora: Its biology, taxonomy, ecology, and pathology. APS Press, St. Paul, Minn.

Smolarz, K., T. Mercik, and S. Mercik. 1982. Growth and fruiting of raspberries on the plots with mineral fertilization diversified since 1923. Fruit Sci. Rpt. 9:159-170.

Stoltz, L.P. 1982. Mineral nutrition studies of american ginseng. Proc. 4th Natl. Ginseng Conf., Lexington, Ky.

von Broembsen, S.L. and J.W. Deacon. 1997. Calcium interference with zoospore biology and infectivity of Phytophthora parasitica in nutrient irrigation solutions. Phytopathology 87:522-528.

Warburton, A.J. and J.W. Deacon. 1998. Transmembrane $\mathrm{Ca}^{2+}$ fluxes associated with zoospore encystment and cyst germination by the phytopathogen Phytophthora parasitica. Fungal Genet. Biol. 25:54-62.

Washington, W.S. 1988. Phytophthora cryptogea as a cause of root rot of raspberry in Australia: Resistance of raspberry cultivars and control by fungicides. Plant Pathol. 37:225-230.

Weste, G. 1983. Population dynamics and survival of Phytophthora, p. 237-257. In: D.C. Irwin, S. Bartnicki-Garcia, and P.H. Tsao (eds.). Phytophthora: Its biology, taxonomy, ecology, and pathology. APS Press, St. Paul, Minn.

Wicks, T. and B. Hall. 1990. Evaluation of phosphonic (phosphorous) acid for the control of Phytophthora cambivora on almond and cherry in South Australia. Australasian Plant Pathol. 19:132-133.

Wilcox, W.F. 1989. Identity, virulence, and isolation frequency of seven Phytophthora spp. causing root rot of raspberry in New York. Phytopathology 79:93-101.

Wilcox, W.F. and M.A. Ellis. 1989. Phytophthora root and crown rots of peach trees in the Eastern Great Lakes regions. Plant Dis. 73:794-798.

Wilcox, W.F. and B.A. Latorre. 2002. Identities and geographic distributions of Phytophthora spp. causing root rot of red raspberry in Chile. Plant Dis. 86:1357-1362.

Wilcox, W.F., J.R. Nevill, and T.A. Burr. 1999a. Susceptibility of red, black and purple raspberry cultivars to three Phytophthora species under greenhouse and field conditions. Acta Hort. 505:241-247.

Wilcox, W.F., M.P. Pritts, and M.J. Kelly. 1999b. Integrated control of phytophthora root rot of red raspberry. Plant Dis. 83:1149-1154.

Wilcox, W.F., P.H. Scott, P.B. Hamm, D.M. Kennedy, J.M. Duncan, C.M. Braiser, and E.M. Hansen. 1993. Identity of a Phytophthora species attacking raspberry in Europe and North America. Mycol. Res. 97:817-831.

Xu-Chang and P.F. Morris. 1998. External calcium controls the developmental strategy of Phytophthora sojae cysts. Mycologia 90:269-275. 